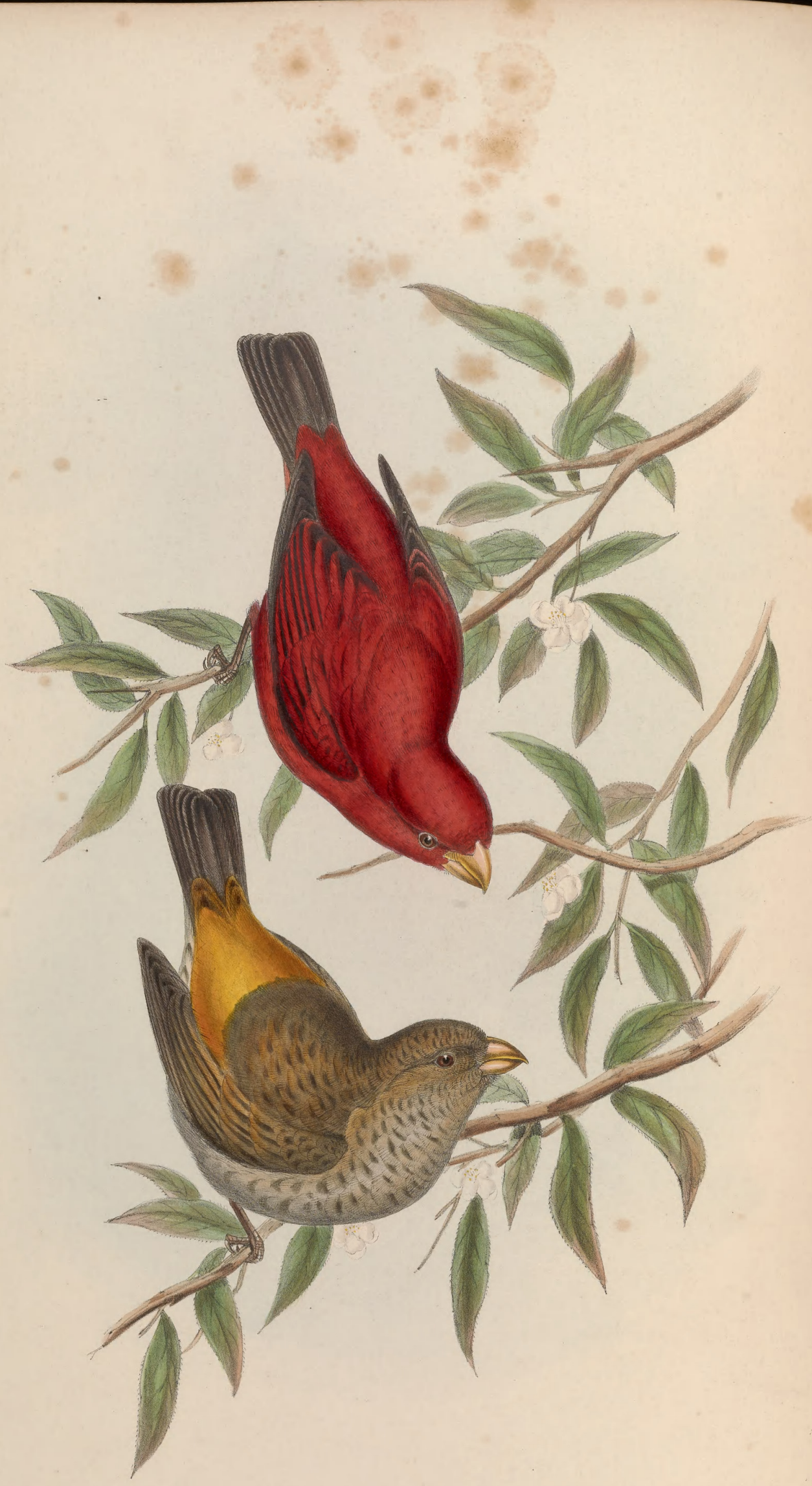

FIENATOSPIZA SIPAHII. 


\section{H EMATOSPIZA SIPAHI.}

\section{Sepoy Finch.}

Corythus Sipahi, Hodgs. As. Res., vol. xix. p. 151.

Propyrrhula Sipahi, Hodgs. in Gray's Zool. Misc., p. 85.

Homatospiza Boetonensis, Blyth, Journ. As. Soc. Beng. 1844, p. 951. pl. fig. 9.

Loxia Indica, Gmel.?

Sipahi, Bonap. et Schlegel, Mon. des Loxiens, p. 33. pls. 39, 40.-Bonap. Consp. Gen. Av. p. 526.
Gmel. ?

- fulgens, Less. Traité d'Orn., p. 447, Coccothraustes, sp. 7 ?

Pitylus coccineus, Cuv.?

Hamatospiza boetonensis?, Blyth Cat. of Birds in Mus. Asiat. Soc. Calcutta, p. 122.

IN many parts of its structure, as well as in its general colouring, this bird offers a close alliance to the members of the genus Corythus, yet every ornithologist will perceive that it differs from that form, and will agree that Mr. Hodgson has very properly made it the type of a new genus, Hamatospiza. It is not only the most highly coloured species of the family Loxiadce, but its plumage is perhaps more intensely scarlet-red than any other at present known; and in its native woods it must be a most attractive and brilliant object, especially if, like its near allies, it be gregarious, and many males may be seen on the same tree at one time. But little information has been recorded respecting this species. It is said to have been received from Darjeeling and the Himalaya, and in all probability the rich country of Nepaul is its native habitat, as it is from thence that specimens have been most frequently brought to this country. Mr. Blyth states, that living examples are occasionally brought to Calcutta for sale; and the Prince of Canino and Dr. Schlegel inform us, in their " Monographie des Loxiens," that it sings very agreeably, and plays a great part in the mythology of the Indians.

The sexes, as will be seen, present a strong contrast to each other.

The male has the entire plumage intense scarlet-red, with the exception of the inner webs of the wingfeathers and the tail, which are black; irides yellowish brown; bill yellowish horn-colour; legs and feet brown.

The female has the feathers of the head, back and wing-coverts dark brown, broadly margined with yellowish olive; rump rich orange ; primaries and tail brownish black, the former margined externally at the base with yellowish olive; tail-coverts brownish black, margined with yellowish olive; feathers of the under surface dark brown at the base, broadly margined with greyish olive; bill browner than in the male.

The Plate represents the two sexes of the natural size. 


\section{$2 \mathrm{BHL}$ Biodiversity Heritage Library}

Gould, John. 1852. "Sepoy Finch, Haematospiza sipahi [PI. 24]." The Birds of Asia 5(IV), -. https://doi.org/10.5962/p.323345.

View This Item Online: https://www.biodiversitylibrary.org/item/121124

DOI: https://doi.org/10.5962/p.323345

Permalink: https://www.biodiversitylibrary.org/partpdf/323345

\section{Holding Institution}

Smithsonian Libraries

\section{Sponsored by}

Smithsonian Institution Libraries

\section{Copyright \& Reuse}

Copyright Status: Not in copyright

This document was created from content at the Biodiversity Heritage Library, the world's largest open access digital library for biodiversity literature and archives. Visit BHL at https://www.biodiversitylibrary.org. 